\title{
Less Invasive Surgery その現状と末来
}

\begin{abstract}
腹腔鏡下胆壤摘出手術が世の注目を浴びてい る。

それはこの手術が従来の手術と異なり，単に 美容的観点から優れているというだけでなく， 患者に与える侵襲が格段に少ないという特徵が あることを，外科医のみならず患者自身が気付 いているからである。

腹腔鏡下胆囊摘出手術は，腹腔鏡というビデ オの目で， $30 \mathrm{~cm}$ を超える長い鉗子類を用いて 外科医が行う新しい手術である。この手術では ビデオの性能と手術用特殊器具の開発, 開腹下 で培った外科医の経験・技量がそれぞれ 3 分の 1 ずつの比重を占めている。
\end{abstract}

腹腔鏡下で胆囊を摘出する作業は，腹壁に開 けるちっぽけな穴で，外科医の手を縛って行う， 器具の手術，インストルメンタルサージェリー である。そこでは外科医の指先のごとく動いて くれる器具の開発が，この手術の安全性や確実 性において致命的重要性を占めている。

又，この手術では，術者は自分の目で直接術 野を見ることができない。カメラマンが術者の 意をくんで“視野出し”をしたビデオモニター の画面を見ながら手術を行うわけである。それ 故ビデオの性能の善し悪しが，手術の成否に直 結しているといっても過言ではない。

腹腔に挿入されるビデオカメラを用いると， 通常の開腹下の手術では見ることのできない角 度から腹腔内臓器を観察でき，また近接すると マイクロサージェリーに近い拡大像が得られる という利点がある。しかし一方で，カメラの目 線が，手術を行う外科医の目線とずれると手術 操作が困難になるという年点や，2次元的表示 しかされないために外科医の解剖学的知識で 3
東京警察病院外科 橋 本 大 定

次元的奥行きを補正しながら手術を行わねばな らないという限界もある。しかしこれらの問題 もわずか 1 年の間で急速に克服されつつある。

私の施設では1991年 3 月に内科が使用してい た旧式の気腹器と, 借り受けた有り合わせの器 具を用いて数例の腹腔鏡下胆表摘出術を何とか 遂行したが，その時点で私は，この方式の手術 法のいくつかの欠点に気付き，当科における手 術を一時中止した。そしてその後の半年間, 福 与さんという優れたエンジニアリングリサーチ ヤ一の協力を得て，この手術に必要とされる機 械や器具の改良を徽底的に加之, かつ, 手術法 にも工夫を重ねてきた。その結果，高価な各種 ディスポ製品を一掃し，再使用可能な，有能な 手術器具を開発するなかで, 気腹器すらも不要 なものとすることができた。そして現在では， どのようにすればより安全・確実・迅速に手術 できるかという問に対し，私なりの答を出せる 所までたどり着けたと考えている。

ここでは, 内視鏡下外科手術の歴史を振り返 りつつ, 従来の気腹法と我々の開発した腹壁吊 ク上げ法とを比較, 解説し, この新しい手術に 必要とされる器械器具開発の現状と問題点を述 べてみたい。

\section{腹腔鏡下手術の歴史}

内視鏡を挿入して体腔内を観察する試みは， 1800年代後半, 各種の管腔臓器を対象として研 究されていたが，その当時の最大の問題点は, ライトソースによる臓器の熱損傷を如何にして 防止するかという点であった。

それゆえ，この分野の研究開発が，水による 冷却効果が期待できる膀胱鏡を中心としてまず 
進められたのは不思議ではない。

腹腔に内視鏡を挿入して観察する最初の試み は, ケリングが1901年膀胱鏡を用いて犬の腹腔 内を観察したのに始まる。ケリングは，視野の 確保とともにライトソースによる腹腔内臓器の 熱損㑺を軽減するために, 腹腔に空気を注射器 で注入してその観察を行った。人の腹腔に膀胱 鏡を挿入して, 初めて腹腔内臓器の観察を行っ たのは，スウェーデンのジャコビウス (1910年) である。しかし，トロッカーや腹腔鏡を直接腹 腔に挿入することに伴う臓器損傷は, 依然とし て大きな問題点であった。

腹壁穿刺に伴う臟器損傷を防止する方法とし て, ベレスは1935年バネ機構を利用して, 針の 先端が筋層では突出し, 腹腔に入ると引っ込む 腹腔穿刺針（ベニスニードル）を考案した。

1946年デッカーは，より安全に腹腔鏡を插入 するルートとして, 経胵的にダグラス窩 (cul$\mathrm{de}-\mathrm{sac}$ )を利用する方法を考案しクルドスコピ 一と名付けている。この方法は局麻下に施行で き, 胸膝位で良好な骨盤内の視野が得られるた め，その後産婦人科領域で積極的に骨盤内を中 心とした腹腔鏡観察が進められた。

1960年代に入ると, 細径のグラスファイバー による光の伝達技術が進み, ライトソースによ る熱損傷の問題が解決され，又，イギリスの木 プキンスによるロッドレンズの開発により，硬 性鏡の性能は顕著に改良された。

改善された硬性鏡を用いて，このころより単 に腹腔内の観察に留まらず，各種の外科的治療 の試みが産婦人科領域において進められた。ド イツのセムは，1965年腹腔内圧を自動的に制御 する機械を開発し，腹腔鏡下で卵管結紮術，卵 巣摘出術或は子宮外妊娠手術などを積極的に試 み報告している。

1970年には，各種波長のレ一ザーが発振され， その医学応用が進められた。又, ランゲンハイ ムやセムらにより各種の腹腔鏡下手術用器具の 開発も進められた。

外科手術への治療応用は, 1987年フランスの フィリップ・モーレが初めて腹腔鏡下で胆霊摘 出を試み, 成功したのが最初である。
腹腔鏡下で外科手術を行うことの優れた点が 広く理解されるに及び, 近年アメリカを始めと して爆発的流行を見ており，その波は本邦にも 押し寄せている。

\section{内視鏡下外科手術と開腹手術の 手術侵襲の違い}

腹腔鏡下で行われる外科手術は，擎く程，低 侵襲である。

実際この手術を受けた患者は，翌日より自立 歩行し，通常の食事を搨取し，2，3 日後には 退院し，元の仕事に復臣できるのである。術後 の創痛は通常軽微であり, 従来の開腹術後に時 折見られる腸閉塞症等の合併症も全くないと言 ってよいほどである。

では，何故腹腔鏡下で行われる手術は，従来 の開腹手術と比べて術後経過がこれほど異なる のであろうか。

通常の開腹法による胆㯬摘出術では, 上腹部 の正中切開もしくは右胁骨马に沿った斜切開で, $15 \mathrm{~cm} \sim 20 \mathrm{~cm}$ 程度の開腹創で手術が行われる。 それに対し，腹腔鏡下胆垔摘出術では，腹壁に 径 $5 \mathrm{~mm}$ 10mm の 4 つの小を開け, 全ての 手術操作が行われる。

腹腔鏡下の手術が患者にとって侵襲が少ない 理由として，先ず第一に，この手術が腹腔の内 部環境を殆ど変えることなく手術が行われる点 が挙げられる。手術室の空調は通常, 感染防御 の目的で患者の直上から周辺に向かって冷たく 清潔で，乾燥した空気が流れるように設計され ている。開腹下の手術では，大網や腸間膜をは じめ, 全ての腹腔臟器が, 広範に直接この異常 環境に晒されることになる。開腹術を受けた患 者は, 殆ど全例といってよい程, 術後数日間は 麻㽻性イレウスの状態となるが，これは腹部の 腸管が長時間, 低温低乾燥状態に晒されること が原因していると考えられる。

また開腹下の手術では，胆资周囲の視野を得 る目的で，胃や十二指腸，横行結腸を後方に圧 排し，肝下面を鉤で頭側に茲引して手術が行わ れている。それに対し，腹腔鏡下胆蓳摘出術で は胆蒦の周囲臟器には殆ど触れることなく, 胆 
囊の部分だけを切除する手術が遂行されるので ある。直接関係のない藏器をいじらないことが, それらの臟器の術後機能に与える影響は少なく ない。

術後の創痛の差に関しては, 皮切の長さが 3 $\mathrm{cm}$ 以上となると腹壁の神経を損傷する可能性 が高くなるという研究がある。直径 $5 \mathrm{~mm}$ ～10 $\mathrm{mm}$ の 4 本のトロッカーを挿入して行う腹腔 鏡下の手術では，三角錐状の内筒針で腹壁に小 孔を押し開けるだけなので，挿入に伴う神経損 傷は先ずないのである。

胆囊摘出術の比較

\begin{tabular}{|c|c|c|}
\hline & 開腹手街 & 腹限鏡下手峳 \\
\hline 手微时間 & 1 1時間30分 & 40 分 1 䟩間20分 \\
\hline 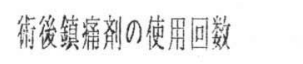 & $3 \sim 5$ 回 & $0 \sim 1$ 回 \\
\hline 蹋後人院期間 & $10 \sim 146$ & $2 \sim 4 B$ \\
\hline 退院から社会復與去での期間 & 2透間 1力月 & $0 \sim \hat{3} \square$ \\
\hline 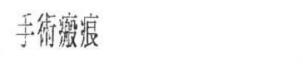 & 大きい & 筬小 \\
\hline 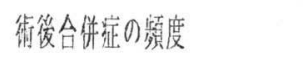 & 多 U & 厸小 \\
\hline
\end{tabular}

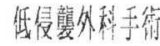

\section{気腹法による腹腔鏡下手術}

気腹法による腹腔鏡下手術とは，腹腔に気体 （主として $\mathrm{CO}_{2}$ ）を注入して腹腔内臓器と前腹 壁との間に空間を確保して行う手術である。そ の空間にトロッカーを穿刺し，外套管を通じて 腹腔鏡や各種の鉗子類を挿入して手術を遂行す るので, 手術の目的に応じた十分な視野空間を 維持する必要がある。

腹壁の挙上される程度は, 腹腔に注入される 気体の量（腹腔内圧）と, 初期の段階では比例 する。さらに気体を注入しつづけると, 最後の 段階では腹壁がそれ以上挙上せず，腹腔内圧だ けが急速に上昇する。組織の毛細血管の抹消圧 は15 20 $\mathrm{mmHg}$ なので, 腹腔内圧がそれ以上に なると，血管内に急速にガスが流入する結果と なるので極めて危険である。そのため通常設定 圧としては12〜15mmHg が選ばれている。
気腹法による手術では，鉗子類のトロッカー 内挿入や，腹腔内吸引によりその都度腹腔内圧 が減少して腹壁が降下するので，高速で気体を 補充する装置は円滑な手術の遂行のために必須 のものである。現在では腹腔内圧をモニターし ながら, 設定された圧力になるまで自動的に高 速で空気の注入を行う器械が開発されている。

気腹法による腹腔鏡下手術では，気腹に起因 した幾つかの合併症が指摘されている。

まず，気腹針（Veress needle）の誤穿刺によ る後腹膜気腫, 消化管内ガス注入, あるいは血 管誤穿刺による腹腔内出血の報告がある。又, 腹腔内を長時間高圧に保つことに起因して, 不 整脈, 心不全, 呼吸不全, 皮下気腫, 縦隔気腫, 下肢静脈血栓症などの合併症が報告されている。 横隔膜は, 腹壁筋より弱いので長時間過伸展さ れる結果となる。気腹法による手術後にかなり の頻度でみられる頑固な肩痛は, その関連痛で ある。

\section{皮下鋼線腹壁吊り上げ法}

筆者が考案した皮下鋼線腹壁吊り上げ法とは， 腹壁の皮下に 2 本の鋼線を挿入し，その鋼線を いわばテントの梁として，皮下鋼線で囲まれる 領域を高く挙上することにより腹腔内に空間を 確保し，手術を行う方法である (Fig. 1)。

この方法で, 腹壁を挙上すると腹腔内は院圧 となるので，腹壁に小孔をあけると（トロッカ 一の抻入）自然に空気が流入し，平圧下の手術 を遂行する事ができる。又, 物理的に腹壁を挙 上するので，気腹法では腹腔内圧が上がりすぎ

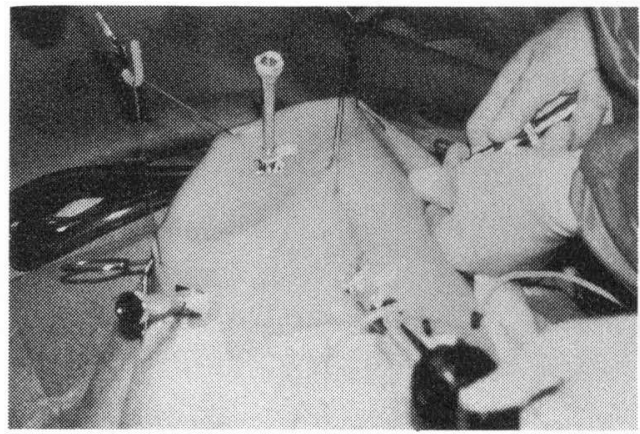

Fig. 1 皮下綱線腹壁吊り上げ法 
て危険となるような高い位置にまで安全に腹壁 を挙上することもできる。又，皮下に捕入する 鋼線の部位は自由に選べるので，目的の手術に 合わせて挙上する腹部領域を選択することもで きるのである。

腹腔鏡下胆和摘出術を行う場合の皮下鋼線の 折入は，右胁省可最下部と右腸骨前状突起のほ ぼ中間で右前腋窝線上の部位を選び，そこにス ピッツメスで $4 \mathrm{~mm}$ の皮切を行う。この創から 径 $3 \mathrm{~mm}$ の 2 本の鋼線を, 1 本は右胁骨局に沿 って, もう 1 本は水平に皮下脂肪組織内に㨂入 し, 臍部で上方に90度屈曲させて剣状突起下ま で抻入し，2本の鋼線を交差させる。ついで正 中部の 2 点及び右側腹部の 2 点で皮下鋼線の下 に，5昂の針付きエチボンド系を通し，両腋窝 腺上の手術台のレールに固定したケント式轶引 器を用いて両側で系を 2 重にしてハンガー上に 挙上する。

吊り上げ法では気腹器を使用しないため, 気 腹法の手術で用いられる逆流防止弁付きの特殊 かつ高価なトロッカーは必要としない。腹壁吊 り上げ法のトロッカーは, $5 \mathrm{~mm}$ と $10 \mathrm{~mm}$ の単 なる金属の简である。

腹壁吊り上げ法による手術では，気腹法の手 術に見られる高二酸化炭素血症, 不整脈, ショ ック, 無気肺, 皮下気腫, 右肩関連痛などの合 併症が皆無であり, 術中横隔膜の動きにより腹 腔内の空気が常時入れ代わるため, 常時鮮明な 視野の下で手術が遂行出来るという利点がある。 又, 結紮や縫合といった気腹下では困難な作業 が容易に行え，手術のランニングコストはほぼ ゼロに近い。

鋼線の挿入に伴う皮下出血が可能性としては 考えられるが，率引により自然止血されるため か, 経験していない。

\section{腹腔に持ち込む目の開発}

腹腔鏡下の外科手術は，ビデオモニターの目 を腹腔に持ち込んで遂行される手術なので, ビ デオモニターの性能は手術の成否に直結する重 要な因子である。ビデオモニターの画像の精度 は, 単板式41万画素 $\mathrm{CCD}$ から 3 板式41万画素
$\mathrm{CCD}$ と近年著しい精度の向上が見られている。 ここでは手術作業を遂行する立場から，著者 らが開発に取り組んできたズーミングカメラ, フォグレススコープ及び三次元内視鏡について 述べる。

\section{ズーミングアダプター}

ズーミングアダプターは, 腹腔鏡のアイピー スとテレビカメラヘッドとの間に装着するアダ プターで, 複数のレンズの組み合わせと移動に より, 焦点が $35 \mathrm{mmF}$ から $150 \mathrm{mmF}$ の範四にわ たってアナログ的に変化するものである。

このズーミング機構を用いると，同じ倍率の 画像が 5 倍以上離れたところで得られ，その部 位で光学視管を動かすことなく, 近接及び全体 観察ができるため，カメラ先端の污染が少なく， 又カメラと銝子の衝突がない。

\section{フォグレス スコープ}

腹腔内に挿入した場合のレンズ而の絬路現象 は，腹腔鏡の持つ問題点の一つである。

この現象は腹腔内の温度が至内温より高く, かつ多湿の環境であることに起因している。

そこで照明系のライトガイドファイバーの一 部を利用して，先端レンズの温度を体温より若 干高めに保ち, 結露を防止するフォグレススコ ープを開発した。

フォグレススコープの開発により, レンズが 酝ったり結露したりするのを確実に防止でき, 常に良好な観察視野のもとに手術を円滑に遂行 することができるようになった。

\section{三次元内視鏡の開発}

従来の腹腔鏡の画面は 2 次元的表示であるた め, 画面の奥行きの判断は, 術者の持つ解剖学 的知識と経験，銝子による触診により行われて きた。それ故，比較的簡単な手術作業は 2 次元 腹腔鏡の観察下でも遂行可能であるが, より複 雑な手術作業となると，その遂行が困難でかつ 長時間を要し手術の安全性や確実性の点で問題 となっていた。

そこで，一定の視差角を持つ 2 本のレンズ系 システムを有するスコープの左右の画像をそれ ぞれ術者の左右の目に知覚させる三次元内視鏡 を開発した。 
開発された時分割式三次元内視鏡は, 約 8 度 の視差角を持つ左右のスコープの画像が $1 / 120$ 秒ずつの間隔で切り替えられて，モニター上に 交互に表示される機構となっている。画像に同 期する液晶シャッターメガネを着用してモニタ 一を観察すると，術者の右目には右側のスコー プの像のみが, 術者の左目には左側のスコープ の像のみが観察されるために, 被観察体が三次 元像として認識されるわけである。

三次元内視鏡の利点は，まず従来の二次元内 視鏡と異なり, 確実な深部感覚 (depth perception）が得られることにある。

液晶シャッターメガネを着用しなければ三次 元視が出来ないという繁雑さがあるが, その有 用性はそれを上回るものである。

三次元内視鏡の問題点としては, 視差角が固 定焦点となっている点が挙げられる。そのため 焦点の前後では良好な三次元視が得られるが, 観察部が焦点から遠く離れると 2 重視となって しまう欠点がある。従って, 手術部位に三次元内 視鏡の焦点を合わせて作業を行う必要性がある。

人の目では被観察体の距離に応じて焦点が自 動的に調節されている。この自動調節機能をも つ内視鏡の開発が今後の課題であろう。

\section{手指の機能を有する鉗子の開発}

腹腔鏡下の手術は, 開腹下の手術と異なり腹 腔内に手を持ち込むことが出来ない。それ故鉗 子の先端部が人の指のように機能する鉗子の開 発が求められている。著者らは径 $5 \mathrm{~mm}$ のトロ ッカーを通過した後, 先端部が90度まで屈曲す るへラ鉗子 (オジギ鉗子) や，それを改良した 結杽用オジギ鉗子を考案して手術を行っている

(Fig. 2)。

今後 2 段にオジギする機能を有する鉗子や, 两方向にオジギする鉗子あるいは把持機能を有 するオジギ鉗子等の開発が期待される。

人が物を把持する場合には, 指の先端の触覚 で固さを知覚しながら必要十分な最低の把持力 で把持している。

腹腔に挿入される鉗子の先端部に繊細な圧力

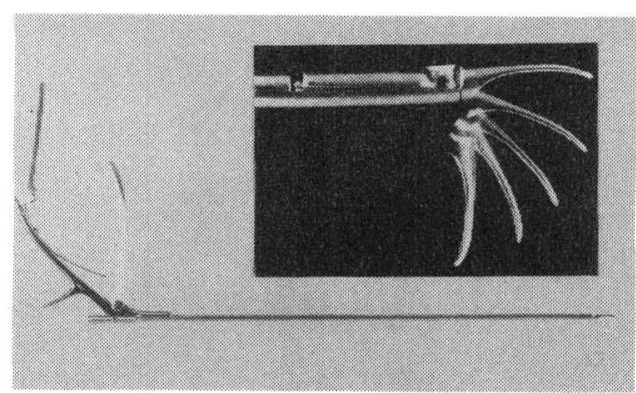

オジギ鉗子

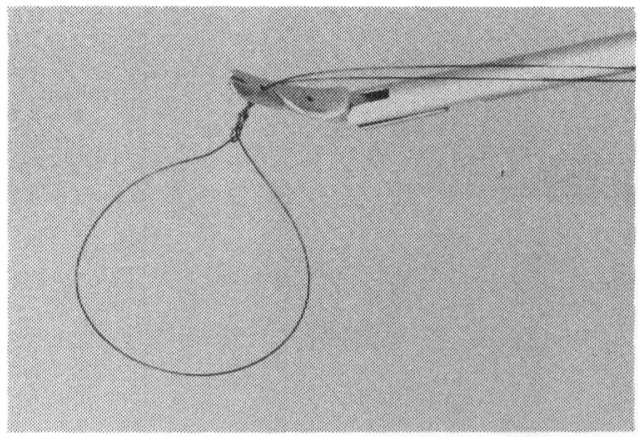

Fig. 2 結禁用オジギ鉗子

センサ一や，あるいはバルーン機構を有する鉗 子を開発する事ができるならば，よりデリケー トな手術操作が出来るようになると思われる。

\section{参考文献}

1) Alfred C and George B: Laparoscopic Biliary Surgery. Blackwell Scientific Publications, 1992.

2) Hashimoto D, et al: Laparoscopic cholecystectomy: an approach without pneumoperitoneum. Surgical Endoscopy, $7:$ 54-56, 1993.

3) Hashimoto D, et al : OJIGI SPATULA: A newly developed movable dissecting Spatula for laparoscopic cholecystectomy. Surgical Laparoscopy and Endoscopy, (In Press).

4) Hashimoto D, et al: Laparoscopic cholecystectomy: First two cases in Bangladesh. Bangladesh Medical Research Council Bulletin, (In Press). 